\title{
Syntheses of 3,4- and 1,4-dihydroquinazolines from 2-aminobenzylamine
}

\author{
Jimena E. Díaz ${ }^{1}$, Silvia Ranieri ${ }^{1,2}$, Nadia Gruber $^{1}$ and Liliana R. Orelli ${ }^{* 1}$
}

\section{Full Research Paper}

\section{Address:}

${ }^{1}$ Universidad de Buenos Aires. CONICET. Departamento de Química Orgánica. Facultad de Farmacia y Bioquímica. Junín 956, (1113)

Buenos Aires, Argentina and ${ }^{2}$ Department of Industrial Chemistry

"Toso Montanari", University of Bologna, Viale Risorgimento 4, 40136

Bologna, Italy

Email:

Liliana R. Orelli* - lorelli@ffyb.uba.ar

${ }^{*}$ Corresponding author

Keywords:

dihydroquinazolines; microwaves; $N$-acylations; $N$-alkylations; PPE

\author{
Beilstein J. Org. Chem. 2017, 13, 1470-1477. \\ doi:10.3762/bjoc.13.145 \\ Received: 20 April 2017 \\ Accepted: 30 June 2017 \\ Published: 27 July 2017 \\ Associate Editor: I. R. Baxendale \\ (C) 2017 Díaz et al.; licensee Beilstein-Institut. \\ License and terms: see end of document.
}

\begin{abstract}
A straightforward strategy for the synthesis of dihydroquinazolines is presented, which allows for the preparation of 3,4- and 1,4dihydroquinazolines with different substitution patterns from 2-aminobenzylamine (2-ABA) as common precursor. The required functionalization of both amino groups present in 2-ABA was achieved by different routes involving selective $N$-acylation and cesium carbonate-mediated $\mathrm{N}$-alkylation reactions, avoiding protection/deprotection steps. The heterocycles were efficiently synthesized in short reaction times by microwave-assisted ring closure of the corresponding aminoamides promoted by ethyl polyphosphate (PPE).
\end{abstract}

\section{Introduction}

Nitrogen heterocycles are part of many drugs and represent structures with wide therapeutic potential. Therefore, much effort has been devoted to the development of efficient, general and expeditious methods for their synthesis $[1,2]$. Cyclic amidines are compounds of interest due to their multiple pharmacological properties, some of which derive from their interaction with a specific receptor $[3,4]$. Six-membered heterocylic amidines (1,4,5,6-tetrahydropyrimidines) display biological ac- tivity as anthelmintics used in medical practice (pyrantel, morantel and oxantel) [5,6], nicotinic agonists [7], antidepressants [8] and selective inhibitors of M1 acetylcholine receptors $[9,10]$, among others. Their benzannulated analogues, dihydroquinazolines, also represent heterocyclic cores of pharmacological interest. Some derivatives containing this motif have shown antimicrobial [11] and antifungal properties [12]. Their activity as selective T-type calcium channel blockers [13-15] and as in- 
hibitors of $\beta$-secretase (an important target for Alzheimer's disease) has been reported [16]. They have also been studied as inhibitors of trypanothione reductase [17], an essential enzyme of the parasite Trypanosoma brucei, and as neuroprotective agents [18].

Different strategies have been used for the preparation of dihydroquinazolines. Some of them involve cyclic precursors such as quinazolinones, quinazolines or tetrahydroquinazolines, which can be reduced or oxidized to yield dihydroquinazolines [17,19-25]. Heterocyclization of acyclic precursors has also been applied for the synthesis of these heterocycles. Many methods use 2-aminobenzylamine (2-ABA) that reacts with amidines, carboxylic acids, orthoformates, or aldehydes in oxidative conditions to yield $N$-unsubstituted dihydroquinazolines [11,16,26-35]. A different approach is based on the heterocyclization of functionalized 2-aminobenzylamines [36,37] such as the cyclization of $\mathrm{N}$-(2-aminobenzyl)amides, which in general requires drastic conditions or long reaction times [17,18,21,22,29,38-40]. Miscellaneous methods include the nucleophilic addition of secondary amines to carbodiimides followed by an intramolecular conjugate addition to an $\alpha, \beta$-unsaturated ester [12-15] or copper-catalyzed annulation of $N$-arylamidines [41], among others [42]. Most of the already mentioned methods have been applied to the synthesis of 3,4-dihydroquinazolines. Among them, only a few were used for the preparation of 1,4-dihydroquinazolines, a heterocyclic framework quite unexplored.

In addition to the heterocyclization itself, the preparation of the acyclic precursors for the synthesis of dihydroquinazolines remains challenging as in some cases it includes a selective $\mathrm{N}$-functionalization of the amino groups of 2-ABA. For example, the selective acylation of the aliphatic amino group was achieved by the treatment of the diamine with benzoic acid in the presence of $\operatorname{Zr}$ (azobenzene-4,4'-dicarboxylate) [43], with tert-butylperoxybenzoate [44] and with isopropenyl acetate [45], or by a DCC-mediated coupling with a carboxylic acid [38]. To our knowledge, selective acylations of $N^{1}$-alkyl-2ABAs have not been reported yet.

Alkylations of the aliphatic amino group of 2-ABA using triflates, halogen or $\mathrm{CCl}_{3}$ derivatives have also been reported. However, these reactions are frequently associated with long reaction times, poor yields and low selectivity $[46,47]$. The selective monofunctionalization of 2-ABA was achieved by using protective groups such as 9-BBN [48] or Boc [39], which require subsequent removal. Other alternative synthetic strategies use substrates like 2-nitrobenzoyl chloride, 2-nitrobenzaldehyde, 2-aminobenzamides, 2-aminobenzophenone, 2-nitrobenzyl bromide, among others, which require an additional reduction step [17,18,29,49-51].

Ethyl polyphosphate (PPE) and trimethylsilyl polyphosphate (PPSE) are mild irreversible dehydrating agents of the Lewis acid type. They have found application for synthetically useful transformations like conversion of amides into nitriles [52,53] or the Beckmann rearrangement $[52,54]$. They have also been widely employed in heterocyclic synthesis, including microwave-assisted reactions. The recognized wide functional group tolerance, stability and low environmental impact are additional advantages of these reagents. Cyclocondensation is a fundamental tool in heterocycles synthesis, and microwave (MW) heating has found interesting applications in this area $[55,56]$, overcoming limitations arising from low reactivity and side reactions typical of conventional heating [57].

We had previously reported the MW-assisted synthesis of 1,4,5,6-tetrahydropyrimidines and their homologues by cyclodehydration reactions promoted by polyphosphoric acid (PPA) esters PPE and PPSE [58-60]. This strategy was successfully applied to the synthesis of 1-aryl-2-imino-1-azacycloalkanes [61], 2-oxazolines, 5,6-dihydro-4H-1,3-oxazines and 4,5,6,7-tetrahydro-1,3-oxazepines [62].

In continuation of this work we herein present an efficient strategy for the synthesis of dihydroquinazolines starting from the easily available 2-ABA as common precursor. The route allows for the preparation of 3,4-dihydroquinazolines 1 and 1,4dihydroquinazolines 2 with different substitution patterns (Figure 1).<smiles>[R]C1=Nc2ccccc2CN1[R]</smiles>

1

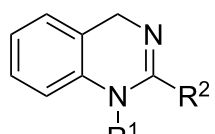

$\mathrm{R}^{1}$

2
Figure 1: 3,4-Dihydroquinazolines 1 and 1,4-dihydroquinazolines 2.

\section{Results and Discussion}

The general synthetic pathways leading to the desired dihydroquinazolines $\mathbf{1}$ and $\mathbf{2}$ are depicted in Scheme 1.

$N$-Alkyl-substituted 2-aminobenzylamines $\mathbf{3 a}-\mathbf{c}$ were readily synthesized by reduction of the amides $\mathbf{4 a - c}$ employing a THF solution of borane (yields $82-93 \%$; see Supporting Information File 1 and Scheme 2).

The synthesis of $N$-(2-aminobenzyl)amides $4 \mathbf{a}-\mathbf{k}$ was achieved by selective $N$-acylation of 2-ABA or its $N$-substituted deriva- 


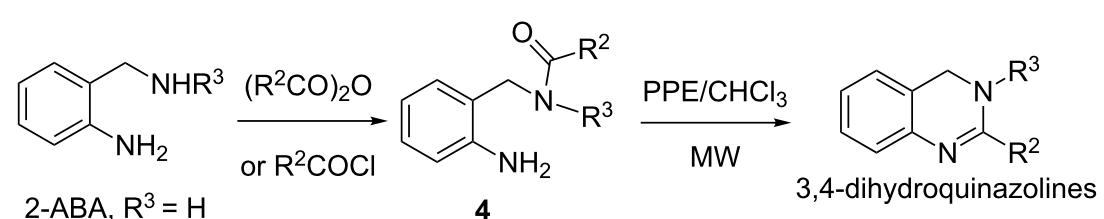

2-ABA, $\mathrm{R}^{3}=\mathrm{H}$

$3, \mathrm{R}^{3} \neq \mathrm{H}$

for $\mathrm{R}^{3}=\mathrm{H} \underset{\mathrm{MW}}{\mathrm{R}^{1} \mathrm{X} / \mathrm{Cs}_{2} \mathrm{CO}_{3} / \mathrm{KI}}$

5
1<smiles></smiles>

2

Scheme 1: Synthetic pathways for the preparation of 3,4-dihydroquinazolines 1 and 1,4-dihydroquinazolines 2.<smiles>NCc1ccccc1N</smiles>

2-ABA

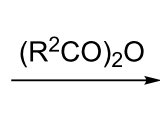<smiles>[R]C(=O)NCc1ccccc1N</smiles>

$4 a-c$

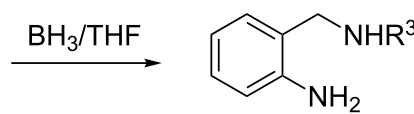

$3 a-c$

Scheme 2: Synthesis of compounds 3a-c

tives 3a-c, whose preparation is depicted in Scheme 2. In spite of the different nucleophilicity of both amino groups, the predictable formation of a hydrogen bond between the aromatic amino group (hydrogen bond donor) and the aliphatic NHR (hydrogen bond acceptor) could increase the nucleophilicity of the former and decrease the reactivity of the latter, favoring the chance for $N, N^{\prime}$-diacylation. To avoid this, the reaction was performed employing a diluted solution of the amine in a biphasic system $\left(\mathrm{CHCl}_{3}\right.$ /aqueous $\left.\mathrm{NaOH}\right)$, low temperature $\left(0^{\circ} \mathrm{C}\right)$ and the use of anhydrides as acylating agents, if commercially available. The results are shown in Table 1.

For $\mathrm{R}^{3}=\mathrm{H}$, products $\mathbf{4 a}-\mathbf{e}$ were obtained in excellent yields when 2-ABA was treated with acid anhydrides as the acylating agents (Table 1, entries 1-5). Replacing anhydrides by acyl chlorides in the reaction the yields were slightly lower, and in some cases small amounts of the $N, N$ '-diacylated products were also obtained (Table 1, entries 6 and 7). Under the same reaction conditions, the $N$-substituted derivatives $3\left(\mathrm{R}^{3} \neq \mathrm{H}\right)$ were selectively acylated with very good yields (Table 1 , entries $8-11)$. Thus, precursors 4 were efficiently prepared by a sequence of $N$-acylation-reduction- $N$-acylation.

The acyclic precursors $\mathbf{5}$, necessary for the synthesis of dihydroquinazolines $\mathbf{2}$, were prepared by $\mathrm{N}$-alkylation of the arylamino group present in compounds 4 using alkyl halides. In a previous work [63], we developed a methodology for the selective $\mathrm{N}$-alkylation of anilines with $\omega$-halonitriles in the presence of cesium carbonate and potassium iodide. There the use of the cesium base prevented $\mathrm{N}$-dialkylation and therefore it was not necessary to use an excess of the amine. This led us to test the same reaction conditions for the synthesis of compounds $\mathbf{5}$. In this case, the presence of the amide functionality was regarded as an additional problem, as $\mathrm{Cs}_{2} \mathrm{CO}_{3}$-mediated alkylation of cyclic amides had already been reported in the literature [64]. In spite of this, compounds 5 were obtained in good to high yields (Table 2) employing the same experimental conditions [63]. The reaction times and temperatures were individually adjusted taking into account the boiling points of the alkylating agents and the reactivity of each substrate.

As expected, the reaction was selective toward the $N$-monoalkylation of the arylamino group in the presence of the amide. Satisfactory results were also obtained using the more hindered isopropyl iodide (Table 2, entries 4 and 8).

Next, the conversion of $N$-(2-aminobenzyl)acetamide (4a) into 2-methyl-3,4-dihydroquinazoline (1a) was chosen for the optimization of the reaction conditions for the synthesis of compounds $\mathbf{1}$. No background reaction was observed when heating a 
Table 1: Selective $N$-acylation of $2-A B A$ and its derivatives.

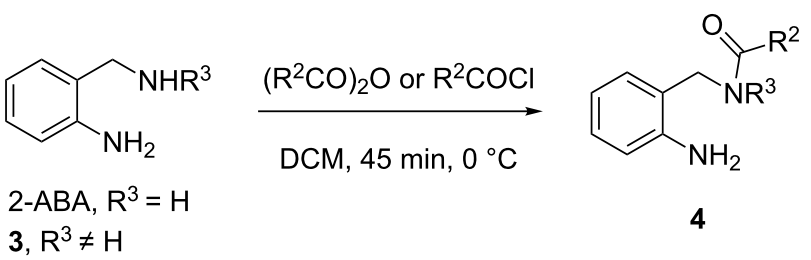

\begin{tabular}{cccccc}
\hline Entry & $\mathbf{4}$ & $\mathrm{R}^{3}$ & $\mathrm{R}^{2}$ & Acylation agent & Yield (\%) $^{\mathrm{a}}$ \\
\hline 1 & $\mathbf{a}$ & $\mathrm{H}$ & $\mathrm{CH}_{3}$ & anhydride & 90 \\
2 & $\mathbf{H}$ & $\mathrm{H}$ & $\mathrm{CH}_{2} \mathrm{CH}_{3}$ & anhydride & 93 \\
3 & $\mathbf{H}$ & $\mathrm{CH}\left(\mathrm{CH}_{3}\right)_{2}$ & anhydride & 94 \\
4 & $\mathbf{d}$ & $\mathrm{H}$ & $\mathrm{C}\left(\mathrm{CH}_{3}\right)_{3}$ & anhydride & 93 \\
5 & $\mathbf{H}$ & $\mathrm{H}$ & $\mathrm{C}_{6} \mathrm{H}_{5}$ & anhydride & 94 \\
6 & $\mathbf{H}$ & $\mathrm{H}$ & $-\mathrm{CH}_{3} \mathrm{C}_{6} \mathrm{H}_{4}$ & acyl chloride & 83 \\
7 & $\mathbf{H}$ & $2-\mathrm{FC}_{6} \mathrm{H}_{4}$ & acyl chloride & 70 \\
8 & $\mathbf{H}$ & $\mathrm{CH}_{2} \mathrm{CH}_{3}$ & $\mathrm{CH}_{3}$ & anhydride & 81 \\
9 & $\mathbf{i}$ & $\mathrm{CH}_{2} \mathrm{CH}_{3}$ & $\mathrm{CH}_{2} \mathrm{CH}_{3}$ & anhydride & 80 \\
10 & $\mathbf{j}$ & $\mathrm{CH}_{2} \mathrm{CH}_{2} \mathrm{CH}_{3}$ & $\mathrm{CH}_{2} \mathrm{CH}_{3}$ & anhydride & 72 \\
11 & $\mathbf{k}$ & $\left.\mathrm{CH}_{2} \mathrm{CH}_{2} \mathrm{CH}_{3}\right)_{2}$ & $\mathrm{CH}_{2} \mathrm{CH}_{3}$ & anhydride & 79 \\
\hline
\end{tabular}

aYields correspond to pure compounds.

Table 2: Synthesis of compounds 5 .<smiles>[R]C(=O)NCc1ccccc1NCc1ccccc1N</smiles>

4

5

\begin{tabular}{|c|c|c|c|c|c|c|c|}
\hline Entry & 5 & $\mathrm{R}^{2}$ & $\mathrm{R}^{1}$ & $X$ & Time $(\mathrm{h})$ & Temperature $\left({ }^{\circ} \mathrm{C}\right)$ & Yield $(\%)^{a}$ \\
\hline 1 & $\mathbf{a}$ & $\mathrm{CH}_{3}$ & $\mathrm{CH}_{2} \mathrm{CH}_{2} \mathrm{CH}_{3}$ & 1 & 5 & 75 & 81 \\
\hline 2 & b & $\mathrm{CH}_{3}$ & $\mathrm{CH}_{2} \mathrm{CH}=\mathrm{CH}_{2}$ & $\mathrm{Br}$ & 4.5 & 65 & 68 \\
\hline 3 & c & $\mathrm{CH}_{3}$ & $\mathrm{CH}_{2} \mathrm{C}_{6} \mathrm{H}_{5}$ & $\mathrm{Cl}$ & 5 & 90 & 64 \\
\hline 4 & d & $\mathrm{CH}_{3}$ & $\mathrm{CH}\left(\mathrm{CH}_{3}\right)_{2}$ & 1 & 6 & 85 & 60 \\
\hline 5 & $\mathbf{e}$ & $\mathrm{CH}\left(\mathrm{CH}_{3}\right)_{2}$ & $\mathrm{CH}_{2} \mathrm{CH}_{2} \mathrm{CH}_{3}$ & 1 & 6.5 & 85 & 67 \\
\hline 6 & $\mathbf{f}$ & $\mathrm{C}\left(\mathrm{CH}_{3}\right)_{3}$ & $\mathrm{CH}_{2} \mathrm{CH}_{2} \mathrm{CH}_{3}$ & 1 & 6 & 85 & 69 \\
\hline 7 & g & $\mathrm{C}\left(\mathrm{CH}_{3}\right)_{3}$ & $\mathrm{CH}_{2} \mathrm{C}_{6} \mathrm{H}_{5}$ & $\mathrm{Cl}$ & 3 & 90 & 60 \\
\hline 8 & $\mathbf{h}$ & $\mathrm{C}\left(\mathrm{CH}_{3}\right)_{3}$ & $\mathrm{CH}\left(\mathrm{CH}_{3}\right)_{2}$ & 1 & 7 & 85 & 75 \\
\hline 9 & i & $\mathrm{C}_{6} \mathrm{H}_{5}$ & $\mathrm{CH}_{2} \mathrm{CH}_{2} \mathrm{CH}_{3}$ & 1 & 7 & 85 & 55 \\
\hline 10 & $\mathbf{j}$ & $2-\mathrm{CH}_{3} \mathrm{C}_{6} \mathrm{H}_{4}$ & $\mathrm{CH}_{2} \mathrm{CH}_{2} \mathrm{CH}_{3}$ & I & 10 & 85 & 71 \\
\hline
\end{tabular}

aYields correspond to pure compounds.

solution of compound $\mathbf{4 a}$ in chloroform for 10 minutes at $130{ }^{\circ} \mathrm{C}$ under MW irradiation in a closed vessel. Using a solution of PPSE in DCM as cyclodehydrating agent, after 30 minutes of reaction under reflux using conventional heating compound 1a was obtained in $86 \%$ yield. Analogous results were obtained using either PPE/ $\mathrm{CHCl}_{3}$ or $\mathrm{PPSE} / \mathrm{CH}_{2} \mathrm{Cl}_{2}$ under microwave irradiation at $110{ }^{\circ} \mathrm{C}$ for 4 minutes. Due to the easier preparation and the inexpensive reagents required for its synthesis [65], PPE was chosen as cyclodehydrating agent for the preparation of compounds $\mathbf{1}$. Results and optimized experimental conditions of the MW-assisted ring-closure reaction are depicted in Table 3. Due to the different reactivity of each substrate, irradiation times and temperatures were individually adjusted. 
Table 3: Synthesis of 3,4-dihydroquinazolines 1.<smiles>[R]C(=O)N([R])Cc1ccccc1N</smiles>

4

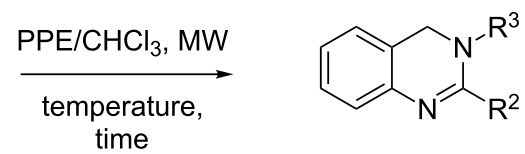

1

\begin{tabular}{|c|c|c|c|c|c|c|}
\hline Entry & Product 1 & $\mathrm{R}^{3}$ & $\mathrm{R}^{2}$ & Time (min) & Temperature $\left({ }^{\circ} \mathrm{C}\right)$ & Yield $(\%)^{\mathrm{a}}$ \\
\hline 1 & $\mathbf{a}$ & $\mathrm{H}$ & $\mathrm{CH}_{3}$ & 4 & 110 & 86 \\
\hline 2 & b & $\mathrm{H}$ & $\mathrm{CH}_{2} \mathrm{CH}_{3}$ & 4 & 110 & 84 \\
\hline 3 & c & $\mathrm{H}$ & $\mathrm{CH}\left(\mathrm{CH}_{3}\right)_{2}$ & 9 & 120 & 76 \\
\hline 4 & d & $\mathrm{H}$ & $\mathrm{C}\left(\mathrm{CH}_{3}\right)_{3}$ & 12 & 130 & 73 \\
\hline 5 & e & $\mathrm{H}$ & $\mathrm{C}_{6} \mathrm{H}_{5}$ & 12 & 130 & 71 \\
\hline 6 & $\mathbf{f}$ & $\mathrm{H}$ & $2-\mathrm{CH}_{3} \mathrm{C}_{6} \mathrm{H}_{4}$ & 15 & 130 & 79 \\
\hline 7 & g & $\mathrm{H}$ & $2-\mathrm{FC}_{6} \mathrm{H}_{4}$ & 15 & 130 & 60 \\
\hline 8 & $\mathbf{h}$ & $\mathrm{CH}_{2} \mathrm{CH}_{3}$ & $\mathrm{CH}_{3}$ & 4.5 & 100 & 98 \\
\hline 9 & i & $\mathrm{CH}_{2} \mathrm{CH}_{3}$ & $\mathrm{CH}_{2} \mathrm{CH}_{3}$ & 8 & 115 & 79 \\
\hline 10 & $\mathbf{j}$ & $\mathrm{CH}_{2} \mathrm{CH}_{2} \mathrm{CH}_{3}$ & $\mathrm{CH}_{2} \mathrm{CH}_{3}$ & 8 & 115 & 86 \\
\hline 11 & k & $\mathrm{CH}_{2} \mathrm{CH}\left(\mathrm{CH}_{3}\right)_{2}$ & $\mathrm{CH}_{2} \mathrm{CH}_{3}$ & 8 & 115 & 80 \\
\hline
\end{tabular}

aYields correspond to pure compounds.

For the synthesis of compounds $\mathbf{1}$ the reaction conditions mainly depended on the steric and electronic features of the amido group present in the substrates. Acetamides and propionamides $\mathbf{4 a}, \mathbf{b}, \mathbf{h}-\mathbf{k}$ reacted readily under mild reaction conditions (Table 3 , entries 1, 2, and 8-11), while for isobutyramide 4c a higher temperature was necessary (Table 3 , entry 3 ). Finally, the more sterically hindered pivalamide $\mathbf{4 d}$ and the less reactive benzamides $\mathbf{4 e}-\mathbf{g}$ required harsher reaction conditions to achieve complete conversion of the substrates and the products were afforded in generally lower yields (Table 3, entries 4-7).

In order to widen the scope of the method, we examined next the applicability of the PPE/MW system to the synthesis of 1,4dihydroquinazolines $\mathbf{2}$. Treatment of precursor 5a with PPE/ $\mathrm{CHCl}_{3}$ under microwave irradiation led to 1,4-dihydroquinazoline $\mathbf{2 a}$, accompanied by a low percentage of a collateral product. This compound was identified as 2-methyl-1-propylquinazolin-4(1H)-one (6a) (Scheme $3,(\mathrm{a}), \mathrm{R}^{1}=\mathrm{Pr}, \mathrm{R}^{2}=\mathrm{Me}$ ), arising from spontaneous benzylic oxidation of 2a. An analogous reaction had been previously reported for 3,4-dihydroquinazolines upon exposure to air (Scheme 3, (b)) [19,24,40,66].

The fact that quinazolin-4(1H)-ones $\mathbf{6}$, which are fully conjugated push-pull molecules, are more resonance stabilized than their isomeric counterparts quinazolin-4(3H)-ones 7, would explain the differential behavior of $N$-substituted 3,4- and 1,4dihydroquinazolines toward spontaneous oxidation.

By the same procedure used for $\mathbf{2 a}$, a series of novel 1,4dihydroquinazolines were synthesized. The results and optimized reaction conditions are reported in Table 4. Due to the different reactivity of each substrate, irradiation times and temperatures were individually adjusted.

Generally the yields for compounds 2 were good to excellent and the experimental conditions and reaction outcome varied depending on the electronic and steric features of the substitu-<smiles>[R]C1=NCc2ccccc2N1[R]</smiles><smiles>[R]C1=Nc2ccccc2CN1[R]</smiles>

[O]

1<smiles>[R]c1nc2ccccc2c(=O)n1[R]</smiles>

7

quinazolin-4(3H)ones

Scheme 3: Benzylic oxidation of 1,4-dihydroquinazolines (a) and 3,4-dihydroquinazolines (b) 
Table 4: Synthesis of 1,4-dihydroquinazolines 2.<smiles>[R]C(=O)NCc1ccccc1N</smiles>

5

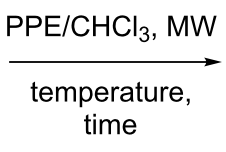

time

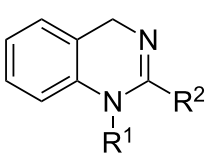

2

\begin{tabular}{|c|c|c|c|c|c|c|}
\hline Entry & Product 2 & $\mathrm{R}^{2}$ & $\mathrm{R}^{1}$ & Time (min) & Temperature $\left({ }^{\circ} \mathrm{C}\right)$ & Yield $(\%)^{a}$ \\
\hline 1 & $\mathbf{a}$ & $\mathrm{CH}_{3}$ & $\mathrm{CH}_{2} \mathrm{CH}_{2} \mathrm{CH}_{3}$ & 11 & 80 & 67 \\
\hline 2 & b & $\mathrm{CH}_{3}$ & $\mathrm{CH}_{2} \mathrm{CH}=\mathrm{CH}_{2}$ & 11 & 90 & 75 \\
\hline 3 & C & $\mathrm{CH}_{3}$ & $\mathrm{CH}_{2} \mathrm{C}_{6} \mathrm{H}_{5}$ & 11 & 90 & 72 \\
\hline 4 & d & $\mathrm{CH}_{3}$ & $\mathrm{CH}\left(\mathrm{CH}_{3}\right)_{2}$ & 12 & 130 & 91 \\
\hline 5 & e & $\mathrm{CH}\left(\mathrm{CH}_{3}\right)_{2}$ & $\mathrm{CH}_{2} \mathrm{CH}_{2} \mathrm{CH}_{3}$ & 21 & 110 & 79 \\
\hline 6 & $\mathbf{f}$ & $\mathrm{C}\left(\mathrm{CH}_{3}\right)_{3}$ & $\mathrm{CH}_{2} \mathrm{CH}_{2} \mathrm{CH}_{3}$ & 20 & 130 & 68 \\
\hline 7 & g & $\mathrm{C}\left(\mathrm{CH}_{3}\right)_{3}$ & $\mathrm{CH}_{2} \mathrm{C}_{6} \mathrm{H}_{5}$ & 25 & 130 & - \\
\hline 8 & $\mathbf{h}$ & $\mathrm{C}\left(\mathrm{CH}_{3}\right)_{3}$ & $\mathrm{CH}\left(\mathrm{CH}_{3}\right)_{2}$ & 25 & 130 & - \\
\hline 9 & $\mathbf{i}$ & $\mathrm{C}_{6} \mathrm{H}_{5}$ & $\mathrm{CH}_{2} \mathrm{CH}_{2} \mathrm{CH}_{3}$ & 13 & 90 & $25^{b}$ \\
\hline 10 & $\mathbf{j}$ & $2-\mathrm{CH}_{3} \mathrm{C}_{6} \mathrm{H}_{4}$ & $\mathrm{CH}_{2} \mathrm{CH}_{2} \mathrm{CH}_{3}$ & 5 & 100 & $39^{b}$ \\
\hline
\end{tabular}

aYields correspond to pure compounds. ${ }^{b}$ The reported yield is approximate and was estimated by integration of suitable ${ }^{1} \mathrm{H}$ NMR signals (see Supporting Information File 1).

ents $\mathrm{R}^{1}$ and $\mathrm{R}^{2}$ present in precursors $\mathbf{5}$. The cyclodehydration of acetamides $\mathbf{5 a}-\mathbf{c}$ proceeded under mild reaction conditions (Table 4, entries 1-3), while acetamide 5d required a higher temperature probably due to the steric hindrance produced by the $N$-isopropyl moiety (Table 4 , entry 4 ). A higher temperature and a longer reaction time were necessary in order to achieve cyclodehydration of isobutyramide $\mathbf{5 e}$, and even harsher conditions were required for pivalamide $\mathbf{5 f}$ (Table 4 , entries 5 and 6 ). In the case of precursors $\mathbf{5 g}, \mathbf{h}$, instead of the expected 1-substituted-2-tert-butyl-1,4-dihydroquinazolines, cyclodehydration led to 2-tert-butyl-3,4-dihydroquinazoline (1d, Table 4, entries 7 and 8), with loss of one $N$-substituent. A possible explanation is that the reaction conditions required in those cases due to steric hindrance bring about a competitive elimination reaction. Finally, as already mentioned, 1,4-dihydroquinazolines 2 are prone to spontaneous oxidation leading to $4(1 H)$ quinazolinones (Scheme 3a) and dihydroquinazolines $\mathbf{2} \mathbf{i}, \mathbf{j}$ showed a comparatively higher lability toward this side reaction. For this reason, the cyclodehydration of the substrates $\mathbf{5 i}, \mathbf{j}$ was carried out at lower temperatures in order to avoid benzylic oxidation. In spite of this, partial oxidation during workup and purification could not be avoided accounting for the lower yields obtained for the 2-aryl derivatives $\mathbf{2 i}$,j (Table 4 , entries 9 and 10). The higher sensitivity of compounds $\mathbf{2} \mathbf{i}, \mathbf{j}$ towards oxidation may be a consequence of the enhanced resonance stabilization of the resulting 2-arylquinazolin-4(1H)ones $\mathbf{6 i}, \mathbf{j}$ (Scheme 3). The fact that the yield of the $o$-methylphenyl-substituted derivative $\mathbf{2} \mathbf{j}$, in which this stabilization is reduced due to steric effects, was higher than for the phenylsubstituted derivative reinforces this hypothesis.

\section{Conclusion}

We have developed novel, general and straightforward strategies for the synthesis of 3,4-dihydroquinazolines with different substitution patterns, starting from 2-ABA as common precursor. An extension of the method allowed for the preparation of $\mathrm{N}$-alkyl-1,4-dihydroquinazolines, a heterocyclic nucleus almost unexplored. To our knowledge, this is the first general method available for synthesis of these compounds. The products were synthesized by microwave-assisted ring closure of different aminoamides promoted by PPE. The yields and reaction times involved in the heterocyclization step compare favorably with the reported methodologies. The preparation of the required aminoamides involves $\mathrm{N}$-acylation and $\mathrm{N}$-alkylation reactions, which were optimized to achieve selective monofunctionalization thus avoiding additional protection/deprotection steps. A judicious combination of these steps into different sequences, allowed for the preparation of both 3,4- and 1,4-dihydroquinazolines with the desired $N$-substitution starting from a single precursor.

The protocols are operationally simple and involve easily available and inexpensive reagents. Due to their widespread use in organic synthesis, the selective $N$-functionalization reactions described herein may find application in many different molecular contexts. 


\section{Supporting Information}

\section{Supporting Information File 1}

Experimental procedures and characterization of new compounds.

[http://www.beilstein-journals.org/bjoc/content/ supplementary/1860-5397-13-145-S1.pdf]

\section{Acknowledgements}

This work was supported by the University of Buenos Aires (20020130100466). We are grateful to Prof. A. Moglioni for providing access to the microwave reactor.

\section{References}

1. Baumann, M.; Baxendale, I. R.; Ley, S. V.; Nikbin, N. Beilstein J. Org. Chem. 2011, 7, 442-495. doi:10.3762/bjoc.7.57

2. Baumann, M.; Baxendale, I. R. Beilstein J. Org. Chem. 2013, 9, 2265-2319. doi:10.3762/bjoc.9.265

3. Doyle, M. E.; Egan, J. M. Pharmacol. Rev. 2003, 55, 105-131. doi:10.1124/pr.55.1.7

4. Szabo, B. Pharmacol. Ther. 2002, 93, 1-35. doi:10.1016/S0163-7258(01)00170-X

5. Austin, W. C.; Courtney, W.; Danilewicz, J. C.; Morgan, D. H.; Conover, L. H.; Howes, H. L., Jr.; Lynch, J. E.; McFarland, J. W.; Cornwell, R. L.; Theodorides, V. J. Nature 1966, 212, 1273-1274. doi:10.1038/2121273b0

6. Anand, N.; Sharma, S., Eds. Approaches to Design and Synthesis of Antiparasitic Drugs; Chapter 6, Vol. 25; Elsevier, 1997.

7. Meyer, E. M.; Arendash, G. W.; Judkins, J. H.; Ying, L.; Wade, C.; Ken, W. R. J. Neurochem. 1987, 49, 1758-1762. doi:10.1111/j.1471-4159.1987.tb02433.x

8. Weinhardt, K.; Wallach, M. B.; March, M. J. Med. Chem. 1985, 28, 694-698. doi:10.1021/jm00383a002

9. Dunbar, P. G.; Durant, G. J.; Fang, Z.; Abuh, Y. F.; El-Assadi, A. A.; Ngur, D. O.; Periyasamy, S.; Hoss, W. P.; Messer, W. S., Jr. J. Med. Chem. 1993, 36, 842-847. doi:10.1021/jm00059a008

10. Dunbar, P. G.; Durant, G. J.; Rho, T.; Ojo, B.; Huzl, J. J., III; Smith, D. A.; El-Assadi, A. A.; Sbeih, S.; Ngur, D. O. J. Med. Chem. 1994, 37, 2774-2782. doi:10.1021/jm00043a016

11. Los, R.; Wesołowska-Trojanowska, M.; Malm, A.; Karpińska, M. M.; Matysiak, J.; Niewiadomy, A.; Głaszcz, U. Heteroat. Chem. 2012, 23, 265-275. doi:10.1002/hc.21012

12. Li, W.-J.; Li, Q.; Liu, D.-L.; Ding, M.-W. J. Agric. Food Chem. 2013, 61, 1419-1426. doi:10.1021/jf305355u

13. Lee, Y. S.; Lee, B. H.; Park, S. J.; Kang, S. B.; Rhim, H.; Park, J.-Y.; Lee, J.-H.; Jeong, S.-W.; Lee, J. Y. Bioorg. Med. Chem. Lett. 2004, 14, 3379-3384. doi:10.1016/j.bmcl.2004.04.090

14. Heo, J. H.; Seo, H. N.; Choe, Y. J.; Kim, S.; Oh, C. R.; Kim, Y. D.; Rhim, H.; Choo, D. J.; Kim, J.; Lee, J. Y. Bioorg. Med. Chem. Lett. 2008, 18, 3899-3901. doi:10.1016/j.bmcl.2008.06.034

15. Byun, J. S.; Sohn, J. M.; Leem, D. G.; Park, B.; Nam, J. H.; Shin, D. H.; Shin, J. S.; Kim, H. J.; Lee, K.-T.; Lee, J. Y. Bioorg. Med. Chem. Lett. 2016, 26, 1073-1079. doi:10.1016/j.bmcl.2015.12.010

16. Ghosh, A. K.; Pandey, S.; Gangarajula, S.; Kulkarni, S.; Xu, X.; Rao, K. V.; Huang, X.; Tang, J. Bioorg. Med. Chem. Lett. 2012, 22, 5460-5465. doi:10.1016/j.bmcl.2012.07.043
17. Patterson, S.; Alphey, M. S.; Jones, D. C.; Shanks, E. J.; Street, I. P.; Frearson, J. A.; Wyatt, P. G.; Gilbert, I. H.; Fairlamb, A. H. J. Med. Chem. 2011, 54, 6514-6530. doi:10.1021/jm200312v

18. Tian, Y.; Ma, C.; Feng, L.; Zhang, L.; Hao, F.; Pan, L.; Cheng, M. Arch. Pharm. 2012, 345, 423-430. doi:10.1002/ardp.201100424

19. Decker, M. Eur. J. Med. Chem. 2005, 40, 305-313. doi:10.1016/j.ejmech.2004.12.003

20. Jaén, J. C.; Gregor, V. E.; Lee, C.; Davis, R.; Emmerling, M. Bioorg. Med. Chem. Lett. 1996, 6, 737-742. doi:10.1016/0960-894X(96)00102-3

21. Armarego, W. L. F. J. Chem. Soc. 1961, 2697-2701. doi:10.1039/jr9610002697

22. Armarego, W. L. F. Adv. Heterocycl. Chem. 1963, 11, 253-309. doi:10.1016/S0065-2725(08)60527-9

23. Smith, J. G.; Sheepy, J. M. J. Heterocycl. Chem. 1975, 12, 231-234. doi:10.1002/jhet.5570120203

24. Richers, M. T.; Zhao, C.; Seidel, D. Beilstein J. Org. Chem. 2013, 9, 1194-1201. doi:10.3762/bjoc.9.135

25. He, K.-H.; Tan, F.-F.; Zhou, C.-Z.; Zhou, G.-J.; Yang, X.-L.; Li, Y. Angew. Chem. 2017, 56, 3080-3084. doi:10.1002/anie.201612486

26. Burdick, B. A.; Benkovic, P. A.; Benkovic, S. J. J. Am. Chem. Soc. 1977, 99, 5716-5725. doi:10.1021/ja00459a032

27. Papadopoulos, E. P.; George, B. J. Org. Chem. 1977, 42, 2530-2532. doi:10.1021/jo00434a049

28. Grasso, S.; Micale, N.; Monforte, A.-M.; Monforte, P.; Polimeni, S.; Zappalà, M. Eur. J. Med. Chem. 2000, 35, 1115-1119. doi:10.1016/S0223-5234(00)01195-8

29. Zhang, J.; Barker, J.; Lou, B.; Saneii, H. Tetrahedron Lett. 2001, 42, 8405-8408. doi:10.1016/S0040-4039(01)01842-1

30. Baxter, E. W.; Conway, K. A.; Kennis, L.; Bischoff, F.; Mercken, M. H.; De Winter, H. L.; Reynolds, C. H.; Tounge, B. A.; Luo, C.; Scott, M. K.; Huang, Y.; Braeken, M.; Pieters, S. M. A.; Berthelot, D. J. C.; Masure, S.; Bruinzeel, W. D.; Jordan, A. D.; Parker, M. H.; Boyd, R. E.; Qu, J.; Alexander, R. S.; Brenneman, D. E.; Reitz, A. B. J. Med. Chem. 2007, 50, 4261-4264. doi:10.1021/jm0705408

31. Hsu, H.-Y.; Tseng, C.-C.; Matii, B.; Sun, C.-M. Mol. Diversity 2012, 16, 241-249. doi:10.1007/s11030-011-9350-1

32. Mercan, D.; Çetinkaya, E.; Şahin, E. Inorg. Chim. Acta 2013, 400, 74-81. doi:10.1016/j.ica.2013.02.005

33. Li, C.; An, S.; Zhu, Y.; Zhang, J.; Kang, Y.; Liu, P.; Wang, Y.; Li, J. RSC Adv. 2014, 4, 49888-49891. doi:10.1039/C4RA09240F

34. Hati, S.; Sen, S. Synthesis 2016, 48, 1389-1398. doi:10.1055/s-0035-1560416

35. Kumar, R. A.; Saidulu, G.; Sridhar, B.; Liu, S. T.; Reddy, K. R. J. Org. Chem. 2013, 78, 10240-10250. doi:10.1021/jo401622r

36. Zhong, Y.; Wang, L.; Ding, M.-W. Tetrahedron 2011, 67, 3714-3723. doi:10.1016/j.tet.2011.03.056

37. He, P.; Wu, J.; Nie, Y.-B.; Ding, M.-W. Eur. J. Org. Chem. 2010, 1088-1095. doi:10.1002/ejoc.200901287

38. Charton, J.; Girault-Mizzi, S.; Debreu-Fontaine, M.-A.; Foufelle, F.; Hainault, I.; Bizot-Espiard, J.-G.; Caignard, D.-H.; Sergheraert, C. Bioorg. Med. Chem. 2006, 14, 4490-4518. doi:10.1016/j.bmc.2006.02.028

39. Dietrich, J.; Kaiser, C.; Meurice, N.; Hulme, C. Tetrahedron Lett. 2010, 51, 3951-3955. doi:10.1016/j.tetlet.2010.05.108

40. Nakagawa, Y.; Stevenst, R. V. J. Org. Chem. 1988, 53, 1873-1876. doi:10.1021/jo00244a007

41. Lv, Y.; Li, Y.; Xiong, T.; Pu, W.; Zhang, H.; Sun, K.; Liu, Q.; Zhang, Q. Chem. Commun. 2013, 49, 6439-6441. doi:10.1039/c3cc43129k 
42. Kreher, R.; Bergmann, U. Heterocycles 1981, 16, 1693-1696. doi:10.3987/R-1981-10-1693

43. Hoang, L. T. M.; Ngo, L. H.; Nguyen, H. L.; Nguyen, H. T. H.; Nguyen, C. K.; Nguyen, B. T.; Ton, Q. T.; Nguyen, H. K. D.; Cordova, K. E.; Truong, T. Chem. Commun. 2015, 51, 17132-17135. doi:10.1039/C5CC05985B

44. Yadav, D. K. T.; Bhanage, B. M. Synlett 2015, 26, 1862-1866. doi:10.1055/s-0034-1380811

45. Pelagalli, R.; Chiarotto, I.; Feroci, M.; Vecchio, S. Green Chem. 2012, 14, 2251-2255. doi:10.1039/c2gc35485c

46. Apfel, C.; Banner, D. W.; Bur, D.; Dietz, M.; Hubschwerlen, C.; Locher, H.; Marlin, F.; Masciadri, R.; Pirson, W.; Stalder, H. J. Med. Chem. 2001, 44, 1847-1852. doi:10.1021/jm000352g

47. Rzasa, R. M.; Kaller, M. R.; Liu, G.; Magal, E.; Nguyen, T. T.; Osslund, T. D.; Powers, D.; Santora, V. J.; Viswanadhan, V. N.; Wang, H.-L.; Xiong, X.; Zhong, W.; Norman, M. H. Bioorg. Med. Chem. 2007, 15, 6574-6595. doi:10.1016/j.bmc.2007.07.005

48. Bar-Haim, G.; Kol, M. Tetrahedron Lett. 1998, 39, 2643-2644. doi:10.1016/S0040-4039(98)00227-5

49. Coyne, W. E.; Cusic, J. W. J. Med. Chem. 1968, 11, 1208-1213. doi:10.1021/jm00312a022

50. Camacho, M. E.; Chayah, M.; García, M. E.; Fernández-Sáez, N.; Arias, F.; Gallo, M. A.; Carrión, M. D. Arch. Pharm. 2016, 349, 638-650. doi:10.1002/ardp.201600020

51. Farhanullah; Samrin, F.; Ram, V. J. Tetrahedron 2009, 65, 1635-1638. doi:10.1016/j.tet.2008.12.041

52. López, S. E.; Restrepo, J.; Salazar, J. J. Chem. Res. 2007, 497-502. doi:10.3184/030823407X245598

53. Kanaoka, Y.; Kuga, T.; Tanizawa, K. Chem. Pharm. Bull. 1970, 18, 397-399. doi:10.1248/cpb.18.397

54. Kanaoka, Y.; Yonemitsu, O.; Sato, E.; Ban, Y. Chem. Pharm. Bull. 1968, 16, 280-284. doi:10.1248/cpb.16.280

55. Van der Eicken, E.; Kappe, C. O., Eds. Microwave-Assisted Synthesis of Heterocycles; Distribution Center, $\mathrm{GmbH}, 2006$

56. Bougrin, K.; Loupy, A.; Soufiaoui, M. J. Photochem. Photobiol., C: Photochem. Rev. 2005, 6, 139-167. doi:10.1016/j.jphotochemrev.2005.07.001

57. Sharma, A.; Appukkuttan, P.; Van der Eycken, E. Chem. Commun. 2012, 48, 1623-1637. doi:10.1039/C1CC15238F

58. García, M. B.; Torres, R. A.; Orelli, L. R. Tetrahedron Lett. 2006, 47, 4857-4859. doi:10.1016/j.tetlet.2006.05.042

59. Díaz, J. E.; Bisceglia, J. Á.; Mollo, M. C.; Orelli, L. R. Tetrahedron Lett. 2011, 52, 1895-1897. doi:10.1016/j.tetlet.2011.02.042

60. Díaz, J. E.; Gruber, N.; Orelli, L. R. Tetrahedron Lett. 2011, 52 , 6443-6445. doi:10.1016/j.tetlet.2011.09.097

61. Díaz, J. E.; Mollo, M. C.; Orelli, L. R. Beilstein J. Org. Chem. 2016, 12, 2026-2031. doi:10.3762/bjoc.12.190

62. Mollo, M. C.; Orelli, L. R. Org. Lett. 2016, 18, 6116-6119. doi:10.1021/acs.orglett.6b03122

63. Link, N. P.; Díaz, J. E.; Orelli, L. R. Synlett 2009, 751-754. doi:10.1055/s-0028-1087817

64. Nivsarkar, M.; Kaushik, M. P. Catal. Commun. 2005, 6, 367-370. doi:10.1016/j.catcom.2005.02.012

65. Pollmann, W.; Schramm, G. Biochim. Biophys. Acta 1964, 80, 1-7. doi:10.1016/0926-6550(64)90192-6

66. Brain, K. R.; Thapa, B. B. J. Chromatogr. 1983, 258, 183-188. doi:10.1016/S0021-9673(00)96410-0

\section{License and Terms}

This is an Open Access article under the terms of the Creative Commons Attribution License

(http://creativecommons.org/licenses/by/4.0), which permits unrestricted use, distribution, and reproduction in any medium, provided the original work is properly cited.

The license is subject to the Beilstein Journal of Organic Chemistry terms and conditions:

(http://www.beilstein-journals.org/bjoc)

The definitive version of this article is the electronic one which can be found at:

doi:10.3762/bjoc. 13.145 